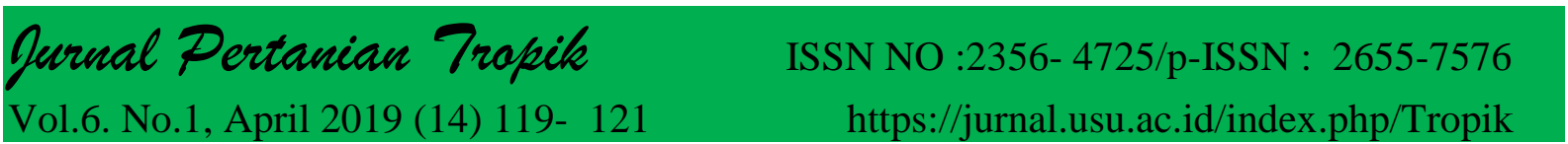

\title{
Respons Pertumbuhan Beberapa Varietas Kedelai (Glycine max L Merr) Terhadap Penggunaan Pupuk Kompos dan Urea
}

Response of Growth of some Soybean Varieties (Glycine max L Merr) on the use of Compost and Urea Fertilizers

\section{Elli Afrida Lubis*, Lisdayani, Putri Mustika Sari}

Program Studi Agroteknologi, Universitas Alwasliyah, Medan- 20147, Indonesia

Correspondence authors: ellilubis@gmail.com

\section{ABSTRACT}

Fertilization has a positive effect on the growth and production of soybean plants. Compost fertilizer is organic fertilizer that is given into the soil can increase nutrients both macro and micro. In addition to the provision of compost fertilizer can also be added to the provision of urea fertilizer (as an inorganic fertilizer) which can provide $N$ nutrients for plants. This study aims to determine the effect of the use of fertilizer (compost and urea) doses with varieties on the growth of soybean plants, and determine the best superior varieties of soybean growth. This study used factorial randomized block design (RBD), with a factor of 1 fertilizer dose, D0: control, D1: compost 5ton / ha, D2: compost 10 tons / ha, D3: urea $25 \mathrm{~kg} / \mathrm{ha}$, and D4: urea $50 \mathrm{Kg} / \mathrm{Ha}$. Factor 2 is the variety with V1: Anjasmoro variety and V2: grobogan variety. The results showed that administration of compost and urea fertilizer can increase soybean plant growth, and also accelerate the flowering age of soybean plants. The grobogan variety has the fastest flowering age of 32.33 days compared to the anjasmoro variety. The role of compost and urea in research increases $N$ elements available to plants.

Key words: Soybeans, compost, urea fertilizer

\begin{abstract}
ABSTRAK
Pemupukan berpengaruh positif terhadap pertumbuhan dan produksi tanaman kedelai. Pupuk kompos merupakan pupuk organik yang diberikan kedalam tanah dapat meningkatkan unsur hara baik makro maupun mikro. Selain pemberian pupuk kompos dapat juga ditambahkan pemberian pupuk urea (sebagai pupuk anorganik) yang dapat memberikan unsur hara $\mathrm{N}$ bagi tanaman. Penelitian ini bertujuan untuk mengetahui pengaruh penggunaan dosis pupuk (kompos dan pupuk urea) dengan varietas terhadap pertumbuhan tanaman kedelai, serta menentukan varietas unggul yang terbaik terhadap pertumbuhan kedelai. Penelitian ini menggunakan rancangan acak kelompok (RAK) faktorial, dengan factor 1 dosis pupuk, D0: kontrol, D1:kompos 5ton/ha, D2 :kompos 10 ton/ha, D3: urea $25 \mathrm{~kg} / \mathrm{ha}$, dan D4 : urea 50 $\mathrm{Kg} / \mathrm{ha}$. Faktor 2 yaitu varietas dengan V1 : Varietas Anjasmoro dan V2 : varietas grobogan. Hasil penelitian menunjukkan bahwa pemberian pupuk kompos dan pupuk urea dapat meningkatkan pertumbuhan tanaman kedelai, dan juga mempercepat umur berbunga tanaman kedelai. Varietas grobogan memiliki umur berbunga paling cepat yaitu 32.33 hari dibandingkan dengan varietas anjasmoro. Peran pupuk kompos dan urea dalam penelitian meningkatkan unsur $\mathrm{N}$ tersedia bagi tanaman
\end{abstract}

Kata kunci : Kedelai, pupuk kompos, pupuk urea

\section{PENDAHULUAN}

Kedelai (Glycine max (L) Merril) adalah komoditas bidang pertanian yang penting dalam penyediaan bahan pangan, pakan, dan bahan baku industri. Sebagai bahan pangan yang penting, kedelai merupakan tanaman yang memiliki sumber 
protein dan lemak yang memadai. Dalam 100 gram kedelai kering terkandung 35 gram protein, 18 gram lemak, 32 gram karbohidrat, 4 gram serat serta air. Minyak kedelai kaya akan vitamin E (Fachruddin dan Lisdiana, 2000).

Dalam hal mengurangi dampak ketergantungan pada impor kedelai, peningkatan produksi kedelai perlu terus diupayakan. Salah satu upaya dalam meningkatkan produktivitas tanaman kedelai, maka perlu usaha pemakaian pupuk sebagai sumber hara. Pemupukan berpengaruh positif terhadap pertumbuhan dan produksi tanaman kedelai. Salah satu ketersediaan unsur hara dalam tanah dan pada tanaman dapat dilakukan dengan cara pemberian bahan organik (Moenandir, 2004).

Pupuk kompos merupakan pupuk organik yang diberikan kedalam tanah dapat meningkatkan unsur hara baik makro maupun mikro yang dapat memperbaiki struktur tanah, meningkatkan daya pegang air, meningkatkan kapasistas tukar kation (KTK) dan memacu aktivitas mikroorganisme tanah yang terlibat dalam proses perombakan bahan organik menjadi unsur hara yang dibutuhkan tanaman seperti unsur $\mathrm{P}$ organik menjadi $\mathrm{P}$ anorganik dengan dosis anjuran pupuk kandang adalah 5-10 ton/ha (Muhidin, 2000).

Selain pemberian pupuk kompos dapat juga ditambahkan pemberian pupuk urea (sebagi pupuk anorganik) yang dapat memberikan unsur hara $\mathrm{N}$ bagi tanaman. Nitrogen merupakan salah satu unsur hara esensial yang sangat diperlukan oleh tanaman dalam jumlah yang cukup banyak. Nitrogen mempunyai peran yang sangat penting bagi pertumbuhan, diantara adalah : (1) sebagai penyusun klorofil; (2) sebagai unsur penyusun asam amino; (3) sebagai pembentukan protein, dan enzim. (Novriani, 2011)

Varietas unggul kedelai memiliki sifat unggul tertentu dibandingkan dengan varietas lokal. Benih varietas unggul dapat meningkatkan produksi tanaman. Sifat unggul tersebut antara lain potensi hasil tinggi, tahan hama dan penyakit, berumur pendek, respon terhadap pemupukan, toleran kekeringan. Penggunaan varietas unggul akan mendorong tanaman tumbuh seragam, masak serempak, produksi tinggi, dan akan meningkatkan efisiensi penggunaan benih (Suhartina, 2005).

Penelitian ini bertujuan untuk mengetahui pengaruh penggunaan dosis pupuk (kompos dan pupuk urea) dengan varietas terhadap pertumbuhan tanaman kedelai, serta menentukan varietas unggul yang terbaik terhadap pertumbuhan kedelai

\section{BAHAN DAN METODE}

Penelitian dilakukan di desa Aras Kabu, Kec. Beringin Kab.Deli Serdang. Penelitian ini dilakukan dari bulan Februari s/d April 2019

Bahan penelitian yang digunakan adalah benih kedelai varietas anjasmoro dan grobogan, pupuk kompos, pupuk urea, polibag Alat-alat yang digunakan dalam penelitian ini berupa cangkul, garu, parang, hand spayer, meteran, gembor, ember, timbangan, pamplet nama, tali, alat tulis dan lain-lain.

Penelitian ini menggunakan rancangan acak kelompok factorial dengan pola factorial $5 \times 2$ dengan 3 ulangan. Faktor yang diteliti meliputi dosis Pupuk (Kompos dan Urea) dan beberapa varietas kedelai. Dosis Pupuk (P) terdiri dari 4 taraf yaitu $: D 0=$ Kontrol ,D1= Kompos 5 ton/ha ,D2 $=\mathrm{kompos} 10$ ton $/ \mathrm{ha} \mathrm{D} 3=$

Urea $25 \mathrm{~kg} / \mathrm{ha}$, D4= Urea $50 \mathrm{Kg} / \mathrm{ha}$

Faktor Varietas (V) terdiri atas 2 taraf, yaitu $: \mathrm{V} 1=$ Anjasmoro, $\mathrm{V} 2=$ Grobogan. Pengamatan dilakukan sebanyak 5 x yaitu pada 14,21,28,35 dan 45 HST. Sifat-sifat tanaman yang diamati yaitu tinggi tanaman, luas daun dan diameter batang

\section{HASIL DAN PEMBAHASAN}

Berdasarkan Tabel 1 dpat diketahui bahwa pengaruh pemberian pupuk kompos 
dan urea memiliki interaksi yang nyata terhadap pertumbuhan tanaman kedelai termasuk dalam hal ini tinggi tanaman kedelai $(\mathrm{cm})$.

Kenyataan tersebut menunjukkan bahwa kompos dan urea merupakan factor yang saling berpasangan dalam menambahkan bahan organi yang dibutuhkan tanaman. Denidi, 2007 melaporkan bahwa peranan unsur nitrogen (N) bagi tanaman berperan dalam merangsang pertumbuhan tanaman secara keseluruhan dan berfungsi untuk sintesa asam amino dan protein dalam tanaman selain itu juga merangsang pertumbuhan vegetatif serta dapat membantu dalam pembentukan klorofil. Selain itu Ketersediaan hara sangat dipengaruhi oleh reaksi-reaksi kimia tanah terutama oleh $\mathrm{pH}$ tanah. Efesiensi dari pemupukan tergantung dari beberapa faktor diantaranya, jenis tanah (sebagai media tempat tumbuh yang paling dominan pengaruhnya) dan jenis pupuk dalam zona perakaran (Muhidin, 2000).

Pada grafik 1 pengaruh pupuk kompos dan urea meningkatkan/ mempercepat umur berbunga tanaman kedelai. Dengan pemberian pupuk kompos 5 ton/ha sudah dapat mempercepat umur berbunga tanaman kedelai. Jenis varietas yang digunakan juga dapat mempengaruhi umur berbungan tanaman kedelai.

Tabel 1. Pengaruh pemberian pupuk kompos dan urea terhadap tinggi tanaman kedelai $(\mathrm{cm})$

\begin{tabular}{|l|c|c|c|}
\hline \multirow{2}{*}{\multicolumn{1}{c|}{ Pupuk }} & \multicolumn{2}{c|}{ Varietas } \\
\cline { 2 - 4 } & V1(Anjasmoro) V2(grobogan) & Rataan \\
\hline D0 (kontrol) & 39.36 & 40.59 & 39.975 \\
\hline D1(kompos 5ton/ha) & 40.82 & 41.29 & 41.055 \\
\hline D2(kompos 10ton/ha) & 42.29 & 42.38 & 42.335 \\
\hline D3(urea 25 kg/ha) & 42.64 & 44.56 & 43.6 \\
\hline D4(urea 50kg/ha) & 43.78 & 44.65 & 44.215 \\
\hline Rataan & 41.78 & 42.69 & 42.235 \\
\hline
\end{tabular}

Ket :Angka-angka yang diikuti oleh huruf yang tidak sama $(a, b)$ pada baris yang sama berarti berbeda nyata pada uji BNJ $\alpha 0,05$.
https://jurnal.usu.ac.id/index.php/Tropik

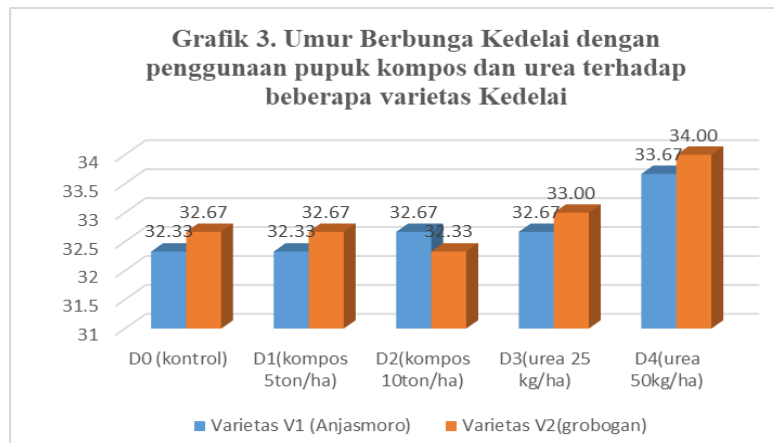

Grafik 1. Umur Berbunga kedelai dengan penggunaan Pupuk (Kompos dan urea) terhadap beberapa varietas Kedelai

Dari grafik 1 dapat dikatakan bahwa varietas grobogan umur berbunga lebih cepat dari varietas anjasmoro. Varietas grobogan umur berbunga 32.33 hari sedangkan anjasmoro 32.67 hari. Kurniawan, Aslim dan Wardati (2013) menyatakan bahwa faktor utama dalam pembungaan pada tanaman kedelai lebih dominan dipengaruhi sifat genetik tanaman. antaman kedelai termasuk tanaman hari pendek dimana kedelai tidak akan berbunga apabila panjang hari melampaui batas kritis, karena masing-masing kultivar memiliki batas kritis yang berbeda.

\section{SIMPULAN}

Pengaruh varietas tidak berbeda nyata terhadap umur berbunga dikarenakan peran pupuk yang digunakan hanya untuk merangsang pertumbuhan tanaman kedelai. Umur berbunga tercepat pada varietas grobogan yaitu 32.73hari. Peran pupuk kompos dan urea dalam penelitian meningkatkan unsur $\mathrm{N}$ tersedia bagi tanaman dikarenakan kandungan $\mathrm{N}$ tersedia pada desa aras kabu masih sangat rendah.

\section{DAFTAR PUSTAKA}

Denidi. 2007. Peran Unsur Hara Pada

Tanaman.http://old.denidi.com/2007/ 11/ fungsi-unsur-hara-makro-np-k.html. diakses 20 april 2019. 
Fachruddin dan Lisdiana. 2000. Budidaya Kacang-kacangan. Kanisius, Yogyakarta.

Idris A. R. 2008. Pengaruh Dosis Bahan Organik Dan Pupuk N, P, K Terhadap Serapan Hara Dan Produksi Tanaman Jagung Dan Ubi Jalar Di Inceptisol Ternate.

Kurniawan, S., Aslim Rasyad, dan Wardati. 2013. Pengaruh Pemberian Pupuk Posfor Terhadap Pertumbuhan Beberapa Varietas Kedelai (Glycine $\max$ (L.)Merril). Jurnal Online. Universitas Riau

Moenandir J. 2004. Prinsip - Prinsip Utama Cara Menyukseskan Produksi Pertanian. Fakultas Pertanian, Universitas Brawijaya. Malang

Muhidin. 2000. Evaluasi toleransi beberapa galur/varietas kedelai (Glycine max L Merril) terhadap cekaman aluminium. Program Pascasarjana, Institut Pertanian Bogor. Bogor

Novriani. 2011. Peranan Rhizobium dalamMeningkatkan Ketersediaan Nitrogen bagi Tanaman Kedelai. Agronobis, Vol. 3, No. 5.

Zainal, M., Nugroho A, dan Suminarty, N.A., 2014. Respon pertumbuhan dan Hasil tanaman kedelai (Glycine max L.Merr) pada berbagai tingkat pemupukan $\mathrm{N}$ dan pupuk kandang ayam. Jurnal produksi tanaman vol 2 No.6 